\title{
Developing International Law in Challenging Times
}

\author{
Thomas Prehi Botchway ${ }^{1} \&$ Abdul Hamid Kwarteng ${ }^{2}$ \\ ${ }^{1}$ Law School, Chongqing University, Shapingba, Chongqing, China \\ ${ }^{2}$ School of Law, Zhongnan University of Economics and Law, China \\ Correspondence: Thomas Prehi Botchway, Room 404, Xuelin Hotel, Chongqing University (Campus A), No. \\ 174 Shazheng Street, Shapingba District, Chongqing, 400044, China. E-mail: abeikuprehi@yahoo.com; \\ prehionline@gmail.com
}

Received: May 17, 2018

Accepted: June 11, 2018 Online Published: August 30, 2018

doi:10.5539/jpl.v11n3p53

URL: https://doi.org/10.5539/jpl.v11n3p53

\begin{abstract}
The challenges confronted by the world in the 21 st century are enormous; from the massive outflow of refugees, the threat of terrorism, the need for a general consensus to protect the environment, etc. There is thus the need for scholars, practitioners, and stakeholders of international law to think of effective and efficient ways of developing robust and strong international laws to deal effectively with these challenges.

Using the qualitative approach to research, this paper examines some of the key challenges that confronts the development of and compliance with international law. The paper offers some new insights which have the propensity to aid in the development of and compliance with international law in these challenging times.

The paper concludes that though international law has over the years expedited addressing most of the world's challenges, the recent challenges requires modifications of some aspects of existing international laws to effectively deal with such challenges. For instance, there is the need to review the veto power of the five permanent members of the UN Security Council; there must be better interpretation of the law that prohibits the use of force, as well as the need for appropriate measures to convince states that abiding by international law is a win-win game. In addition, deploying economic diplomacy and applying the Corporate Social Responsibility Approach to Building International Law (CRASBIL) are deemed meaningful for developing international law and also achieving effective compliance.
\end{abstract}

Keywords: effective international laws, global challenges, veto power, UN Security Council, Corporate Social Responsibility Approach to Building International Law (CRASBIL)

\section{Introduction}

It is an undisputed fact that the world is currently confronted with numerous challenges in different areas ranging from terrorism crises, justice, the massive outflows of refugees, the need to protect the ecology, Brexit, as well as economic and political challenges. Though some scholars have argued that states do not have any moral obligations to obey or comply with international law (Posner, 2003; Reus-Smit, 2003), it is the view of the authors that international law, nevertheless has a greater responsibility in developing effective and efficient measures in dealing with all these challenges. It is therefore incumbent on scholars, professionals, and students of international law to critically examine the current global challenges of both public and private international law so as to come out with possible solutions to develop international laws capable of effectively dealing with these challenges as and when they arise. The paper postulates that the existence of effective legal rules in the international system will foster compliance with regime norms by "providing channels for dispute-settlement" and "requiring states to furnish information regarding compliance" (Koh 1997, p.2625), thereby reducing unnecessary retaliatory actions while ensuring compliance at the same time.

International law over the years has provided the platform and framework for dealing with global challenges with regards to international relations. It does this through various means, among which includes the offering of legal solutions to problems all over the world through the development of substantive areas of law as well as the provision of court systems to adjudicate and settle disputes and misunderstandings that arise when States, non-governmental organisations (NGOs), and individuals relate among themselves (Garriga-Lafabregue, 2017). International law however is constantly faced with new challenges due to the rapidly changing circumstances occurring in various parts of the world on daily basis. Thus challenges such as armed conflicts, unprecedented 
health crises, climate change, gender inequality, global terrorism, cyber insecurity (eg. the 2008 cyber-attacks on Georgia, the alleged interference by Russia in the 2016 US elections, etc.) (Swaine, 2008), rising challenges to intellectual property rights, questionable international trade practices, etc., goes a long way to test the adaptability, dynamism and robustness of international law. This has necessitated the need for academics, scholars and practitioners of international law to think of innovative ways by which international law could be framed or reshaped to deal with all these challenges in a much effective manner (Chauvet, 2017).

This paper aside contributing to the existing literature on the subject of international humanitarian law (IHL) and international investment law (IIL) also proposes a different approach to handling issues. Thus, it recommends the application of practical models for resolving pertinent issues that have gradually engulfed the effective practice, implementation, and development of IHL, IIL, and other aspects of international law. It must however be emphasised that the paper does not purport to be a panacea to the numerous challenges that faces researchers and practitioners alike in their attempt at developing and strengthening coherent international laws, rules and regulations; neither can it serve as an antidote to cure states of their sometimes genuine (and even ill-willed) positions and national interests. It instead recommends that taking a closer look at the suggested approaches (as elaborated below) could rather create a relatively win-win situation for all actors and make our world a more peaceful and secured place for us and for posterity.

\subsection{Methodology}

The methodology adopted for the study is the qualitative approach. This is due to the fact the approach is much suitable for explanatory and descriptive studies (Babbie, 2004). Adopting this approach enabled the authors to dwell on existing works in the field that have focused on researching on how to develop international law and ensure compliance to meet the challenging circumstances of the world. The adoption of a qualitative approach of analysis aid the researchers in obtaining relevant data on the topic under discussion which consequently resulted in obtaining a rich and in-depth insight into the research questions (Patton, 2005). The approach also enabled the researchers to begin the study with a philosophical assumption and offered the opportunity for the researchers to bring on board their own perspective about the issue under discussion and finally created a platform for the use of interpretive and theoretical frameworks to further shape the study in order to arrive at meaningful conclusions (Creswell, 2012).

The study primarily relied on secondary sources of information such as documents from the internet, journal articles, policy documents as well as other important reading materials such as the dailies, press releases, news items and official reports.

\subsection{Outline of the Paper}

The paper is divided into five major sections. The first section as can be seen above, gives an introduction to the paper by drawing attention to the fact that there are indeed a number of challenges facing international law in contemporary times. The section then throws light on the significance of the study and concludes by outlining the methodology that the authors adopted in undertaking this study.

The second part of the paper identifies some of the key challenges related to the development of and compliance with international law. This is then followed by the third section which proposes five thematic areas through which international law can be developed and its compliance enhanced. Whereas the authors give their concluding remarks in the fourth section, the final section (section five) is dedicated to recommendations on the subject under consideration.

\section{Challenges to the Effectiveness of International Law in Challenging Times}

Studies have shown that there has always been a connection between international trade and investment law, as well as sovereign debt, the conduct of multinational corporations, human rights, and climate change, and that these issues have not been effectively addressed by the existing international law instruments (Fitzgerald, 2015). It has been argued that the existing international instruments and mechanisms actually "tend to impede action to address the most pressing issues of the day" and that although the incremental improvements of the existing legal instruments are useful, the current "grave human rights violations" calls for "serious remedies" and "not merely soft-law voluntary codes and mediation" (Fitzgerald 2015, p. 2).

\subsection{Politics and Power Struggle in the International System}

The interplay of politics in the international arena as well as the quest for power by States in the international system is an undisputed phenomenon that cannot be ruled out if one is making an analysis of factors that hinder the effectiveness of international law in recent times. In other words, the differences in ideology between states, especially, between the West and the East/North and South, have permeated the practice and application of 
international law in recent times and as such it makes it difficult to reach a consensus between the five permanent members of the United Nations Security Council (UNSC) to respond to situations of emergency that will help implement international law, especially international humanitarian and human rights laws. The Syrian Crisis, Malaysian Airline flight MH17 and the 2007 draft resolution on the peace and security of Myanmar are typical cases by which the ideological difference between the North and South has prevented the adoption of a resolution to respond to emergency situations where lives and properties are threatened (Kwarteng \& Botchway, 2018).

Closely related to this problem of North and South divide is the power of veto that is accorded to the five permanent members of the UNSC. Although the power of veto given to the five permanent members of the Council has its advantage, the ideological difference between the Global developed North Countries (the USA, France, and UK) and that of the Global developing South Countries (China and Russia) serves as an obstacle for the effective performance of the UN Security Council. In other words, due to the fact that a veto from one permanent member implies that a resolution cannot be adopted, matters of urgency are delayed in most cases before a consensus will be reached among the five permanent members at which time lots of lives and properties may have been lost already.

\subsection{Double Standards and Unilateral Decisions}

Another challenge to the effectiveness of international law could be attributed to the seemingly double standards that international law engenders. Thus, whereas rich and powerful States occasionally breach one international law or the other without being held accountable for their actions, the presumably weak and poor States on the other hand are made to face the consequences of their actions in the event that they go contrary to established international laws and norms (Cooper-Cunningham, 2015). This phenomenon creates a situation where weak and poor countries tend to believe that international law does not exist to serve their common good and that international law is a tool developed by the West or powerful countries to serve their own agenda and interest and probably use it to exploit the weak and poor countries.

This conviction eventually dampens the spirit and commitment of relatively weak and poor countries in abiding by international laws and standards, especially, in developing countries where international law seeks to advance and promote the rights of the vulnerable such as women and refugees. For example, most countries refuse to sometimes accept refugees in their territory and in the case that they accept these refugees in their countries, they fail to implement the rights and priveleges that refugees are supposed to enjoy in a host country as stated by the UN's 1951 convention on the rights and status of refugees to which most of these states are signatories to (Kwarteng, 2018; Refugee crisis in Europe, 2018).

In addition, unilateral decisions that some countries usually take with regards to issues of international global concerns usually serves as a very heavy challenge to implementing certain key internationally agreed proposals and resolutions. This in effect affects effective implementation of international law. The US is quite guilty of such occurrences and this has even become worse with the Trump administration. Thus issues such as pulling out of the Paris Agreement, the recognition of Jerusalem as the Jewish capital, incessant attack on the UN, EU, NATO, African and Caribbean countries, the seemingly antagonistic policy towards the East (particularly China), the unilateral introduction of new taxes and tariffs on steel and aluminum, the use of missiles on Syria and Afghanistan, etc., all point to how much burdens are been placed in the way of international law and cooperation on issues of common concern (USA Today, 2017; Hindustan Times, 2017; Earle, 2017).

\subsection{The Problems with Definition and Application of IHL}

Indeed given the evolving patterns in modern warfare and the predominance of non-international armed conflicts, as well as the rapid emergence of non-State actors in the contemporary legal, political, and concrete reality of IHL, several conditions have caused both state and non-state actors to disregard their obligation of compliance during periods of armed conflict (Kwarteng \& Botchway, 2018; Kelley, 2013). Several problems arise from the use of the Geneva Conventions and their protocols to administer IHL, especially given the complicated nature of modern warfare and conflict practices. Moreover, since non-State actors are "not privy to the international laws governing them", there is always the issue of "denial of consent and participation in rule making" and this does little to ensure that these non-State actors will abide by the standards which they have not consented to and participated in its formulation (Kelley 2013, p. 18). This situation eventually poses as a challenge to enforcing international law, thus the need to develop new laws to meet the requirements of the time. IHL have over the years regulated the actions of non-State actors in armed conflicts, but given the fact that these non-State actors are becoming more influential than ever, there is also the need for "better application, implementation and compliance with IHL in contemporary times" (Kelley 2013, p. 16).

Civilians have over the years been the victims of violations of the IHL. They are often used as human shields, 
murdered, encounter forced disappearance, torture, cruel treatment and outrages upon personal dignity, as well as rape and other forms of sexual violence. Even medical personnel and humanitarian workers who are usually on the field to offer medical assistance to both the civilians and the belligerents are also most of the times been targeted by IHL violations (International Committee of the Red Cross (ICRC), 2007). A recent example is the situation in Northeastern Nigeria and Myanmar's Rakhine region where even media personnel have been targeted for giving coverage to the alleged ethnic cleansing of the Rohingya Muslim minority. Such activities as a matter of fact hampers the efforts of humanitarian organizations from carrying out their activities and further aggravates the plight of those whom they are meant to assist and protect (ICRC, 2007).

Moreover, the hypocrisy of states in denying the applicability of IHL to certain situations, even in situations where the facts on the ground clearly indicates that they are 'guilty', and the fact that some states "have attempted to broaden the scope of application of IHL to include situations that could not, based on the facts, be classified as armed conflicts" (ICRC2007, p. 720), serves as an impediment to international law and its development. In addition, the ICRC (2007) has also indicated that the predisposition by some actors (being it state or non-state actors) to call attention to alleged violations by others, without showing any willingness to admit ongoing violations of their own, has also been detrimental to the proper application of IHL. In other words, the egotistic attitude adopted by states and the method of " "picking and choosing' when and how the rules of IHL can apply, should be regarded as one of the gravest threats to humanitarian norms that the world is currently facing" (Kelley, 2013, p. 25).

\subsection{The War on Terror, National Security and Implications on IHL}

In this age of terror and counter-terrorism operations, the political objectives of military campaigns have become steadily predicated on the concrete outcome of particular military operations with the total eradication of threats becoming the end goal of these political strategies. This situation coupled with the fact that most of these military campaigns commences and even progresses without considerable vision on how to address the potential disparities and ways to restoring stability in the aftermath have actually given grounds to questioning how one can achieve an acceptable balance between essential humanitarian concerns and short-term political and security objectives (Maurer, 2012). This situation also has negative consequences on compliance with international law. Classical examples of this scenario include the US invasion of Iraq in 2003, the 2011 overthrow of Muammar Gaddafi and Israel's occupation of Palestine (Hinnebusch, 2007; Karuri, 2016; Maurer, 2012).

The former US President, Barack Obama is believed to have confessed that he failed "to plan for the day after what I think was the right thing to do in intervening in Libya" (Karuri, 2016). With regard to Israel's activities in the in the Occupied Palestinian Territory - that is, the West Bank, East Jerusalem, and the Gaza Strip, using the 1907 Hague Regulations, as well as the Fourth Geneva Convention, and other equally related relevant customary IHL, Maurer (2012) has argued that "compliance with and respect for IHL - while by no means a panacea - would significantly reduce human suffering on both sides, and would help restore confidence and ultimately offer the best chance of preparing the ground for a peaceful resolution of the conflict" (Maurer, 2012, p. 1506).

\subsection{Excessive Regionalism and Self-Preservation}

The introduction of the EU Directive on Ship Source Pollution, which can be seen as imposing rules beyond what is allowed under the 1982 United Nations Convention on the Law of the Sea (UNCLOS) and the International Convention for the Prevention of Pollution from Ships (MARPOL), is a significant example of legislative initiatives which exceed internationally agreed standards. For instance, the Directive limited the effect of certain exceptions to liability in MARPOL, with a resultant expansion of potential liability to additional parties beyond those set out in MARPOL, and it also in some cases removed the crucial distinction between accidental and deliberate discharges (Breide \& Saunders, 2018). Considering the strength of the EU as a regional body and the influence it exerts in the international system, such a regional directive that runs contrary to internationally accepted practice indeed serves as an obstacle to international law.

Moreover, laws such as Sri Lanka's Prevention of Terrorism Act of 1979 (PTA) with the broad powers it provides law enforcement agents and the guarantee of immunity for officials responsible if they are deemed to be acting in good faith (without defining the scope of what would constitute acts done in 'good faith') have over the years undermined IHL and human rights law. For instance, the PTA refutes detainee rights and also shifts the evidentiary burden of proof to the detainee alleging torture or ill-treatment (International Commission of Jurists (ICJ), 2017). Moreover, according to the ICJ (2017), the most gross human rights violations and serious violations of IHL that "amount to crimes under international law, such as enforced disappearances, extra-judicial killings, war crimes and crimes against humanity, are not criminalized as offenses under Sri Lankan domestic law" (p. 6). 


\section{Making International Law Effective in Challenging Times}

The last two and half decades have witnessed considerable efforts been made to ensure that individuals responsible for serious violations of IHL are prosecuted and punished. Thus, throughout this period, apart from the operations of the International Criminal Court and special or mixed tribunals, ad hoc tribunals have also been established to help deal with violations of IHL (ICRC, 2007). According to the ICRC, though these developments are useful and should continue, there is the need to pay particular attention to improving compliance with IHL while an armed conflict is going on. The Committee is also of the view that "it is of utmost importance that preventive mechanisms be consolidated if the law is to fulfil its protective role" and that states and their corresponding actors "have a crucial role to play in such an effort" (ICRC 2007, p. 744).

The ICRC (2007) argues that it is the failure to implement existing norms that has become the main cause of suffering during armed conflicts and of violations of IHL, and that this failure could be attributed to the absence of political will or to another reason rather than "a lack of rules or their inadequacy". According to the Committee, "the law is just one among many tools used to regulate human behaviour" and as such "no branch of law, whether international or domestic, can - on its own - be expected to completely regulate a phenomenon as complex as violence" (p. 721). In other words, there will always be States and non-State actors who, irrespective of the penalties involved, will not be deterred from violating international laws.

As indicated by the ICRC (2007), the development and clarification of customary international law, as well as the law applicable in non-international armed conflicts has not necessarily eradicated some of the major challenges to IHL. It is therefore postulated that attempts at addressing the current seemingly disorder around the globe cannot be remedied just by applying laws. The authors at this point would reiterate the argument of Fernando R. Teson that indeed "the traditional approach to the problem of international obligation", and for that matter international law, "is incomplete and much too simplistic" (Teson1990, p. 85), and that in modern times, there is the need to approach international law and its consequent obligation on states from new perspectives. Hence, all other elements that influence human conduct such as the socio-cultural, as well as the political, and the economic must be taken into account when contemplating comprehensive solutions to developing new modes of interactions between states and non-state actors as well as between and among belligerents.

\subsection{Addressing the Seeming Inequality}

To begin with, international law can be made effective to deal with the current challenges of the world by providing adequate, effective, and efficient procedures to resolve cases from zero-sum game to win-win game. Thus all actors in the international system act rationally with the hope that they will be better than the other, but this, in fact, leads to chaos. International law can help here by providing the appropriate language and measures to convince states that abiding by international law, customs and norms is a positive win-win game for all States and not a zero-sum game where one state benefits at the expense of the other states. Such measures could include effective mediation, conciliation, and arbitration, while the using courts to settle disputes should be the last resort.

In this regard, it will be relevant to cite the numerous efforts been spearheaded by China and the Association of Southeast Asian Nations (ASEAN) to redress various issues pertaining to territorial boundaries in the subregion. Thus, the signing of the various memorandum of understanding and the efforts at undertaking jointly owned and supported development in these contested regions are important steps towards achieving mutual benefits, development, preventing chaos, and eventually promoting international law and cooperation as well as world peace (ASEAN Secretariat, 2017; ASEAN-China, 2017). On this note, the authors would also like to draw attention to some countries that hide behind the argument of freedom of navigation to foment troubles in the region that what the world needs is peace, stability and development, not wars and chaos as we are seeing in Libya, Iraq, Syria, Afghanistan, Sudan, Somalia, etc.

Again the veto power vested in the five permanent members of the UN Security Council should be reviewed in order to make the UNSC more effective in responding to emergency situations where the lives of people are threatened. Thus, there is the need to overhaul the entire voting pattern of the UN Security Council, especially when issues of international humanitarian and human rights are involved (Kwarteng \& Botchway, 2018). As a matter of fact, the composition of that structure which is itself a vestige of the Second World War also showcases that indeed the sovereignty and equality of all states, as stipulated by the UN Charter is just a hoax. This lopsided posture of the UN and particularly the Security Council does not encourage trust and enhance the responsibility of states and the execution of their obligations under international laws. As a result, addressing this perennial problem would go a long way in ensuring good faith among states that have always felt under represented and sidelined. This would also help reduce the perception and belief that international laws are usually promoted by the developed nations with the intension of suppressing developing nations and keeping them below the ladder of 
development.

The point been established here is that, instead of the 'veto' power been vested in the hands of the five permanent members, the Council should adopt a 'reverse consensus' (a system which would imply that if any of the five permanent members would like to veto a resolution, it must be able to convince the others, at least $50 \%$ of the non-permanent members present and voting) to agree with its position and in the event that a permanent member is not able to convince $50 \%$ of the non-permanent members to agree with its veto, then that veto will not work and hence cannot prevent the adoption of a resolution (Kwarteng \& Botchway, 2018). If such a system is adopted, it will curtail the "unnecessary veto" of the five permanent members. This will go a long way to encourage developing and other non-permanent members to be assured their proper role in the international system and hence reduce their sometimes seemingly reluctance to abide by some these resolutions and international laws in general since they know they are active participants in the system.

\subsection{Proper Interpretation of Existing Laws}

The laws prohibiting the use of force should be better interpreted to reflect the current situation and reality of the twenty-first century. Article 2(4) of the UN Charter comprehensively prohibits the use of force (Delbruck, 1993), as it enjoins "All Members" to "refrain in their international relations from the threat or use of force against the territorial integrity or political independence of any state, or in any manner inconsistent with the Purpose of the United Nations". The initial intention of Article 2(4) of the UN Charter was to apply the principle with regards to the prohibition of the use of force only to international use, or threat of use of force (Delbruck, 1993). However, in recent times and with the current challenges of the world, prohibition of the use of force is not only limited to the international use of force but also extended to the internal use of force, especially in situations where the internal use of force has a greater possibility of constituting a threat to international peace and security or in the event that such an event could lead to massive human rights violations and this should be inculcated into the interpretation of the prohibition of the use of force so as to reflect the current realities of the $21^{\text {st }}$ century.

\subsection{Taming Excessive Regionalism}

The UN and other internationally recognised institutions should put in more efforts to ensure that there is no regional breakup with regards to the global conception of what constitute the core components of international law. Thus, activities aimed at promoting excessive, domineering, hegemony over competing subsystems and overarching regionalism which places much importance on regional bodies with regards to the application and practice of international law should be limited. This is not to suggest a leviathan global system, instead, the point is to ensure that the rules, practices, and policies of regional and subregional groupings do not contradict with those of the universally accepted laws to which such groups are parties. Hence regional organizations will not assume a more important role or supremacy over the basic universal norms that form the core of international law which must be cherished among all nations.

In addition, the continuous rise of China and the consequent evolution of the world into bipolarity has a greater potential of creating a situation where regionalism will form the basis of the practice and application of international law, but this phenomenon, however, could have a negative effect on the practice of international law as it might lead to a situation where regional interest will be much more important and paramount than the interest of the general good which will hinder the effectiveness of international law hence the need for measures to prevent such a phenomenon from occurring. In other words, just as the sovereignty of individual states are expected to be subjected to international law, so should that of regional and subregional groupings be equally subjected to the generally accepted international law.

\subsection{The Corporate Social Responsibility Approach to Building International Law (CRASBIL)}

The CRASBIL opines that in the creation and establishment of any transnational corporation (TNC), the parties involved should sign an agreement stipulating the responsibilities of all parties on the essence of an effective corporate social responsibility. That is to say the agreement should clearly outline the roles and obligations as well as the benefits and burdens to all parties, including the host state, investor state, the TNC and the subsidiaries. Thus, this agreement should be reflected in both existing and future bilateral or multilateral investment treaties among states, and that rewards should be attached for effective compliance while noncompliance attracts penalties.

The point must be reiterated that under the current international human rights law structure, corporations do not have any meaningful international legal obligations; these obligations are usually borne by states (McCorquodale, 2009; Thabane, 2014). Thus, even where a state or its official is even not directly responsible for the actual violation of an international human rights law, the state can still be held responsible for a lack of positive action in responding to, or preventing, the violation of such human rights by corporations and other nonstate actors 
(McCorquodale, 2009, p. 387). In other words, the concepts of state responsibility and complicity puts undue burdens on states while TNCs virtually always escape from their abuses by hiding behind the principles of limited liability, and territoriality/jurisdiction. This situation therefore calls for states to be able to "regulate and control corporations that are incorporated or active in that state (corporate nationals)" to ensure non-violations of human rights or "face effective sanctions if they do" (McCorquodale2009, p.389).

Thus, bearing in mind that "most corporations respond better to preventative regulation by a state than to reactive litigation, not the least because it reduces uncertainty and risk" (McCorquodale, 2009, p. 394), the existing practice that postulates that a state can only have jurisdiction over its own nationals, and that it can rarely enforce this jurisdiction in another state's territory must be revised. In other words, the practice whereby most transnational corporations (TNCs) operate through subsidiaries incorporated in host states, and not incorporated in the state of the headquarters of the TNC makes it exceedingly difficult to hold the extended enterprise accountable for human rights abuses and must thus be revised as well (August, Mayer, \& Bixby, 2013; McCorquodale, 2009; Ruggie, 2008). This when done effectively would mean such TNCs and their subsidiaries can be held responsible for malpractices in host states. Moreover, it would also mean that TNCs and their subsidiaries can have better and effective cooperation with the host state and would be able to follow a well framed programme aimed at contributing meaningfully to their host states as would be agreed upon in a CRASBIL.

On this note, it must be stated that the argument that postulates that the apparent merging of CSR policies and human rights is fraught and creates confusions since "each of them operates fundamentally differently" (McCorquodale, 2009, p. 393), is quite shaky. This stems from the fact that the merging of CSR policies and human rights issues in a more coherent manner would help to ensure the wellbeing of the very people for whom these corporations exist for (since they are the consumers of the products or services from these corporations). Thus the social, economic, and cultural benefits that these people may derive from the merger of CSR and human rights policies would in turn put them in a better position to patronize their goods and services while at the same time minimizing the likelihood of expropriation and unwarranted litigations with their attendant heavy cost for all stakeholders in the long run.

The CRASBIL if effectively implemented would also serve as a potent marketing tool for TNCs and their subsidiaries as it aids in cementing social capital in host states. Consequently, in the fields of international investment and trade laws, the question of unwanted and unwarranted expropriation and unnecessary litigations can be minimized if efforts will be made to strengthen and encourage corporate social responsibility on a broad and sustainable scale. Thus, much efforts should be made to develop friendly but enforceable standards of conduct and mechanisms that will not just hold corporations accountable for human rights violations, bribery and corruption, as well as environmental degradation committed in their operations around the world (Fitzgerald, 2015), but also encourage sustainable policies aimed at improving the lives of host communities. The point here is that an effective corporate social responsibility approach to building international law (CRASBIL) agenda can be a major tool in an attempt at developing practical, durable and friendly yet effective international law. This approach if followed meticulously would have a long reaching positive effect on the development and application of resilient international laws across the globe.

The point must also be made that the effective application of resilient CRASBIL has the tendency to reduce drastically the substantial commercial interests that are usually associated with investor-state disputes, and the attendant large monetary awards to private investors and concomitant burdens on taxpayers. It could also serve as an effective tool for mitigating the frequent challenges to the perceived national security and public policy of sovereign states. In addition, applying a CRASBIL effectively can limit the growing concerns that have characterised the development and democratic approaches to international law. This stems from the fact that an effective $C R A S B I L$ would not overlook the national security and the public policy of states, just as it would not undermine democratic practices.

Consequently, the questions of accountability and transparency, as well as impartiality and coherent jurisprudence, would be addressed effectively since the CRASBIL would require adherence to domestic laws while not neglecting international regulations. It would also mean ensuring that the interest of both the host state and that of the foreign investor are all duly catered for. This in turn will go a long way in establishing effective international trade and foreign investment laws. This would also enable international law to resolve the long held view of the development critique that developed countries usually establish rules which developing countries "have no choice but to accept, and that the promise of investment leading to development has not been realized" (Fitzgerald 2015, p. 2).

Considering the fact that realistically speaking economic security is at the heart of all state interactions, an introduction of the CRASBIL in state interactions and cooperation will enhance compliance and strengthen 
international law. An example of how the $C R A S B I L$ can induce states to comply with international law can be seen from Israel under Netanyahu in the late 1990s. Thus, despite his ardent opposition to the Oslo accords as an opposition leader of Israel's right-wing Likud party, Benjamin Netanyahu after winning the elections and becoming the prime minister completed and implemented an agreement with Yasser Arafat and the Palestinian Authority as was negotiated by the Oslo accords. Thus, considering national interest and identity at stake, as well as acceptance in the international society coupled with the high economic dividends anticipated, all helped in shaping Netanyahu and Israel's return to compliance with international law, and cooperation with the Palestinians and other moderate Arab nations such as Egypt and Jordan in the late 1990s (Koh, 1997). The point here is that notwithstanding the conservative position of the Likud party, and Netanyahu's personal idiosyncrasy, the promise of economic gain could not be overlooked, hence the need to adjust and embrace cooperation. The point must be noted that notwithstanding the shaky nature of the Middle East peace process, an effective incorporation of the $C R A S B I L$ in international law have the tendency to do more than most ancient and modern approaches have failed to achieve.

In a similar vein, Iran's recent compliance to refraining from developing its nuclear programme can be attributed to the promising and huge economic package that the Iran Nuclear Deal entails. Thus, the conservative state being rational and examining its interests and that of global peace carefully decided to comply with the dictates of the deal mainly because of the economic package (U.S. Department of State, 2018; BBC, 2017). Reference can also be made to the Democratic People's Republic of Korea (DPRK) and its seemingly compliance in the early and mid-1990s when the US and other western nations attempted to lure it to abandon its nuclear programme (Taylor, 2016). This once again goes to affirm how the introduction and effective application of the CRASBIL would ensure effective compliance with international law.

\subsection{Diplomatic and Strategic Deployment of IHL}

During times of conflict, attempts by agencies and institutions to merely make the parties involved aware of the existing laws or of their specific obligations is not enough to ensure compliance. Thus, aside making known these rules and regulations to combatants, much more should be done. Moreover, in order to ensure that parties develop a receptive and positive attitude towards these laws, the presentation should be done tactically. This implies that peace brokers must know and understand the parties' incentives and interests in engaging in the conflict (ICRC, 2007). The law must also be explained in a manner that is relevant and adapted to the context of the existing conflict. This, if done effectively would trigger the urge to compliance to IHL and could eventually lead to the laying down of arms in the long run. The point here is that diplomacy, even in the midst of war has a higher propensity to quench wary flames.

\section{Conclusion}

From the above, one can argue that the need to develop strong and robust international laws to deal with the current challenges of the world is of great importance and as such scholars, academics, practitioners, and stakeholders of international law have a great responsibility of determining ways and means by which international law could be effectively developed to deal with the challenges of the twenty-first century.

International laws over the years have gone a long way in helping to address most of the situations and challenges facing the world, but the recent challenges that the world faces requires modification of some aspects of the existing laws as well as the introduction of new ones so as to effectively deal with such challenges. As the paper has indicated, some of the areas that need modification include, but not limited to, a review of the veto power of the five permanent members of the UNSC; a better interpretation of the law that prevents or prohibits the use of force; the application of the CRASBIL; and the diplomatic and strategic deployment of IHL. These modifications and enhancements will go a long way to aid international law in effectively dealing with the current challenges of the world.

Moreover, in an attempt to ensuring compliance with IHL by violent non-state actors in contemporary warfare, it is imperative that the States must act in a way that exemplifies correct behavior in times of armed conflicts. This in turn has a higher propensity to encourage behaviors of positive reciprocity by the non-state actors.

Since "history teaches us that markets pose the greatest risks - to society and business itself - when their scope and power far exceed the reach of the institutional underpinnings that allow them to function smoothly and ensure their political sustainability", and given the fact that "the root cause of the business and human rights predicament today lies in the governance gaps created by globalization", as identified by the Ruggie Report (Ruggie, 2008, p. 1), there is the need to find effective ways of bridging these gaps and ensuring that all stakeholders enjoy the mutual benefits of globalization. The authors are of the view that the CRASBIL and the other approaches outlined earlier if promoted would aid in bridging these gaps and also promote entrepreneurship while at the same time curbing 
corporate impunity (Thabane, 2014).

\section{Recommendations}

It is recommended that effective and sustainable measures should be instituted to enable the USA and the People's Republic of China and their respective allies to bury their ideological differences and perceived competition between these countries. Instead, there should be collaboration with each other in developing strong and effective international laws that can help mitigate or perhaps eliminate some of the challenges of the twenty-first century such as the threat of terrorism, massive inflow of refugees, the promotion and protection of the rights of the vulnerable and so on.

There is also the need for much publicity and education about the importance and relevance of international law, especially in developing countries due to the fact that the first and perhaps the biggest problem of international law in developing countries is the lack of its popularity. Thus, since people are not aware of their rights and privileges, as far as international law is concerned, they are not able to press the government and other stakeholders to ensure that their rights as enshrined in international and regional instruments of which their governments are signatory are ensured as expected. For example in some developing countries, the vulnerable such as persons with disabilities and women are denied most of their rights and privileges especially in employment and high public and political decision making positions that they are to enjoy as far as international law is concerned. However, because in most cases the people themselves are not aware of the existence of such rights and privileges, they cannot or do not have any motivation to pressure their governments to ensure that their rights as stated by international laws and conventions are ensured hence the need for education and publicity of international law.

Finally, effective implementation of IHL both in peacetime and in armed conflicts should be a constant priority for all actors in the international system.

\section{Acknowledgements}

The authors are grateful to Benedicta Brobbey for her insightful comments and proofreading of the initial draft of the manuscript.

\section{References}

ASEAN Secretariat. (2017, June). Overview of ASEAN-China Dialogue Relations. Retrieved March 21, 2018, from http://asean.org/storage/2017/06/Overview-of-ASEAN-China-Relations-June-2017.pdf

ASEAN-China. (2017, November 13). Joint Statement between ASEAN and China on Further Deepening the Cooperation on Infrastructure Connectivity. Retrieved from http://asean.org/storage/2017/11/China-and-ASEAN-on-Cooperation-Connectivity-CN-ASEAN_adopted.p df

August, R., Mayer, D., \& Bixby, M. (2013). International Business Law: Text, Cases, and Readings. Pearson: Boston.

Babbie, E. (2004). The practice of social research. Belmont, CA: Wads-Worth.

BBC. (2017, October 13). Iran nuclear deal: Key details. Retrieved from http://www.bbc.com/news/world-middle-east-33521655

Breide, C., \& Saunders, P. (2018, March 15). Challenges to the Unclos Regime: National Legislation Which Is Incompatible with International Law. Retrieved https://www.iho.int/mtg_docs/com_wg/ABLOS/ABLOS_Conf5/Papers/Session5-Paper2-Breide.pdf

Chauvet, C. (2017, August 11). International Law in Challenging Times. Retrieved February 26, 2018, from https://chanelchauvet.com/2017/11/08/my-perspective-on-international-law-weekend/

Cooper-Cunningham, D. (2015, December 14). Should Irregular Fighters Be Excluded From Legal Protections Such As POW Status? Retrieved March 29, 2018, from http://www.e-ir.info/2015/12/14/should-irregular-fighters-be-excluded-from-legal-protections-such-as-powstatus/

Creswell, J. W. (2012). Qualitative inquiry and research design: Choosing among five approaches (3rd ed.). Thousand Oaks, CA: Sage.

Delbruck, J. (1993). A More Effective International Law or A "New World Law"? Some Aspects of the Development of International Law in a Changing International System. Indiana Law Journal, 68(3), 704-725.

Retrieved

March

29 ,

2018 ,

from 
https://www.repository.law.indiana.edu/cgi/viewcontent.cgi?referer=https://sg.search.yahoo.com/\&httpsredi $\mathrm{r}=1$ \&article $=1506 \&$ context $=\mathrm{ilj}$

Earle, G. (2017, January 25 ). Trump attacks the United Nations with dramatic funding cuts and moves to halt treaties. Retrieved

from http://www.dailymail.co.uk/news/article-4158014/Trump-attacks-dramatic-funding-cuts.html

Fitzgerald, O. (2015). Emerging Issues in International Trade and Investment Law: An International Economic Law Consultation Workshop. Toronto: Centre for International Governance Innovation (CIGI).

Garriga-Lafabregue, L. (2017, November 8). International Law in Challenging Times (ILW-NY). Retrieved March 29, 2018, from http://law.wustl.edu/harris/lexlata/?p=2015

Hindustan Times. (2017, September 28). Civilian killed as US missile malfunctions during airstrike on Taliban in Kabul. Retrieved from https://www.hindustantimes.com/world-news/civilian-killed-as-us-missile-malfunctions-during-airstrike-on -taliban-in-kabul/story-yhGRPxwQhVHjgffW5RLfEM.html

Hinnebusch, R. (2007). The American Invasion of Iraq: Causes and Consequences. Perceptions, 9-27.

International Commission of Jurists (ICJ). (2017). Challenges to Accountability for Human Rights Violations in Sri Lanka. Geneva: International Commission of Jurists (ICJ).

International Committee of the Red Cross (ICRC). (2007). International humanitarian law and the challenges of contemporary armed conflicts. International Review of the Red Cross (Reports and Documents).89 , pp. 719-757. Geneva: International Committee of the Red Cross.

Karuri, K. (2016, April 11). Obama: Aftermath of Gaddafi overthrow, 'worst mistake as president'. Retrieved March 22, 2018, from http://www.africanews.com/2016/04/11/obama-aftermath-of-gaddafi-overthrow-worst-mistake-as-president

Kelley, M. (2013). Challenges to Compliance with International Humanitarian Law in the Context of Contemporary Warfare. Independent Study Project (ISP) Collection. Paper 1618, The University of Texas at Austin, SIT Graduate Institute/SIT Study Abroad, Austin.

Koh, H. H. (1997). Why Do Nations Obey International Law? The Yale Law Journal (Faculty Scholarship Series. Paper 2101), 2598-2659. Retrieved from http://digitalcommons.law.yale.edu/fss_papers

Kwarteng, A. H. (2018). The Application and Practice of International Refugee Laws in Ghana: A Case Study of Egyeikrom Refugee Camp. Asian Research Journal of Arts \& Social Sciences, 5(3), 1-11. https://doi.org/10.9734/ARJASS/2018/39406

Kwarteng, A. H., \& Botchway, T. P. (2018). The North and South Divide in the Practice and Application of International Law: A Humanitarian and Human Right Law Perspective. Journal of Politics and Law, 11(1), 79-87. https://doi.org/10.5539/jpl.v11n1p79

Maurer, P. (2012, Winter). Challenges to international humanitarian law: Israel's occupation policy. Geneva: International Committee of the Red Cross.

McCorquodale, R. (2009). Corporate Social Responsibility and International Human Rights Law. Journal of Business Ethics, 87, 385-400. https://doi.org/10.1007/s10551-009-0296-5

Patton, M. Q. (2005). Qualitative research. New Jersey: John Wiley \& Sons, Ltd. https://doi.org/10.1002/0470013192.bsa514

Posner, E. A. (2003). Do States Have a Moral Obligation to Obey International Law? Stanford Law Review, 1901-1920.

Refugee crisis in Europe. (2018, March 21). Refugee crisis in Europe. Retrieved from https://refugee-crisis.eu/?vote=yes\&option $=1 \& \mathrm{~h}=43 \mathrm{~b} 79460 \mathrm{~d} 817 \mathrm{~d} 1 \mathrm{dbaf} 9 \mathrm{~cd} 94531 \mathrm{fbc} 7 \mathrm{a} 0 \#$ vote-message

Reus-Smit, C. (2003). Politics and International Legal Obligation. European Journal of International Relations, 9(4), 591-625. https://doi.org/10.1177/135406610394003

Ruggie, J. (2008). Report of the Special Representative of the Secretary-General on the Issue of Human Rights and Transnational Corporations and Other Business Enterprises-Protect, Respect and Remedy: A Framework for Business and Human Rights. United Nations, United Nations Human Rights Council . New York: United Nations. Retrieved March 27, 2018, from http://www.reports-and-materials.org/Ruggie-report-7-Apr-2008.pdf 
Swaine, J. (2008, August 11 ). Georgia: Russia 'conducting cyber war' . Retrieved from https://www.telegraph.co.uk/news/worldnews/europe/georgia/2539157/Georgia-Russia-conducting-cyber-w ar.html

Taylor, A. (2016, January 6). The slow death of the nuclear deal with North Korea. Retrieved from https://www.washingtonpost.com/news/worldviews/wp/2016/01/06/the-slow-death-of-the-nuclear-deal-wit h-north-korea/?utm_term $=.944 \mathrm{c} 115300 \mathrm{~b} 8$

Teson, F. R. (1990). International Obligation and the Theory of Hypothetical Consent. Yale Journal of International Law, 15(1), 83-120.

Thabane, T. (2014). Weak extraterritorial remedies: The Achilles heel of Ruggie's 'Protect, Respect and Remedy' Framework and Guiding Principles. African Human Rights Law Journal, 14, 43-60.

U.S. Department of State. (2018, March 21). Joint Comprehensive Plan of Action. Retrieved from https://www.state.gov/e/eb/tfs/spi/iran/jcpoa/

USA Today. (2017, April 6). U.S. launches cruise missile strike on Syria after chemical weapons attack. Retrieved from https://www.usatoday.com/story/news/politics/2017/04/06/us-launches-cruise-missile-strike-syria-after-che mical-weapons-attack/100142330/

\section{Appendix}

\section{List of abbreviations}

ASEAN - Association of Southeast Asian Nations

BBC - British Broadcasting Corporation

Brexit - British Exit from the European Union

CRASBIL - Corporate Social Responsibility Approach to Building International Law

DPRK - Democratic People's Republic of Korea

EU - European Union

ICJ - International Commission of Jurists

ICRC - International Committee of the Red Cross

IHL - international humanitarian law

IIL- international investment law

MARPOL - International Convention for the Prevention of Pollution from Ships

NATO - North Atlantic Treaty Organisation

NGOs - non-governmental organisations

PTA - Prevention of Terrorism Act of 1979, Sri Lanka

TNCs - Transnational Corporations

UK - United Kingdom

UN - United Nations

UNCLOS - United Nations Convention on the Law of the Sea

UNSC - United Nations Security Council

US - United States of America

\section{Copyrights}

Copyright for this article is retained by the author(s), with first publication rights granted to the journal.

This is an open-access article distributed under the terms and conditions of the Creative Commons Attribution license (http://creativecommons.org/licenses/by/4.0/). 